\title{
KATHARINA KEHL
}

\section{Homonationalism Revisited:}

\author{
Race, Rights, and Queer Complexities
}

\begin{abstract}
As various "right kind of queers" make their way into the social mainstream, researchers have moved their attention from compulsory heterosexuality as queer theory's main other towards the new normativities created by these "exclusive integrations". This article looks at existing critiques of homonormativity, homonationalism and homocolonialism and asks how we can develop these concepts, in order to maintain their relevance for well-needed analyses of the role LGBT rights play in projects of (national) boundary-making, as well as the ways in which LGBTQ people are variously positioned to deal with these. I argue that we need to take into account the ways in which these concepts have developed as they have entered new academic disciplines while also re-engaging with one of the central aspects of Puar's initial framing of homonationalism: The racialised nature of sexualised/gendered difference. The article discusses the excessive potential of "gay-rights-as-human-rights" discourses, Cynthia Weber's "plural logics of and/or" in order to challenge seemingly straightforward narratives of homonationalism, homonormativity and homocolonialism. It also draws on Alexander Weheliye's "Habeas Viscus" in order to renew our theoretical engagement with questions of racialisation and colonialism, and to expand our view beyond issues of (legal) recognition.
\end{abstract}

Keywords: homonationalism, queer theory, racialisation, LGBTQ, human rights 


\section{Introduction}

In recent decades, "queerness" and the social movements associated with it have experienced an unprecedented move into the societal mainstream of particularly North American and Western European democracies, with LGBTQ people gaining the legal right to marry, raise children and serve in the armed forces. As certain "right kind of queers" (Sabsay 20I2) are integrated into various heteronormative social institutions, heteronormativity seems to increasingly have run its course as queer theory's main adversary. But what may look like "the best of times" (Dhawan 2013, I9I) for queer politics has been critiqued by scholars who question the "exclusive inclusions" upon which these moves into the mainstream are predicated, the (neo)colonial and (neo)imperial national and international hierarchies enabled by them and the contradictory ways in which "queerness" is celebrated, instrumentalised and fiercely policed (Puar 2007; Rao 2014; Haritaworn, Kuntsman, and Posocco 2013; Rahman 20I4). These analyses of how understandings of "normative" and "deviant" sexualities and gender identities play into various practices of (national) boundary-making, have extended queer theory's reach into various academic fields, such as migration studies, human rights studies, and, most recently, international relations (Luibhéid 2008a; Rao 20I4a; Richter-Montpetit 2018; Langlois 2015). However, as critiques of homonormative, homonationalist and homocolonialist narratives have become more established within (and outside) academic discourses, they have themselves been subjected to scholarly scrutiny, criticised for a tendency towards simplifications and generalisations that obscure the contingencies, ambiguities and complexities of particular formations of knowledge/power/pleasure (see e.g. Weber 2016b).

This article asks how we can develop these concepts in order to maintain their relevance for well-needed analyses of the role figurations of "L-G-B-T-Q" play in projects of boundary-making as well as the ways in which LGBTQ people are variously positioned to deal with these. I argue that we need to take into account the ways in which they have developed as concepts as they have entered new academic disciplines. We also need to re-engage with one of the central aspects of Puar's 
initial concept: The racialised nature of sexualised/gendered difference. By re-connecting new conceptualisations to this core aspect of the original critique, we will be able to better account for the complexities and "messiness" of contemporary queer positionalities as they relate to various exclusive inclusions, as well as for the question of which queer bodies can and cannot afford to "not want rights".

The following section provides an introductory summary of the concepts homonormativity, homonationalism and homocolonialism as well as the discourse on "gay-rights-as-human-rights" and its global implications. I will then go on to nuance and develop these critiques, focussing on three main aspects. Firstly, I discuss the excessive potential of "gay-rights-as-human-rights" discourses as more than just expressions of (neo)colonialism and (neo)imperialism as well as queer communities' inability to "not want rights". Secondly, I employ Cynthia Weber's "plural logics of and/or" in an attempt to challenge seemingly straightforward narratives of homonationalist/homonormative processes of boundary-making. Finally, I draw on black studies scholar Alexander Weheliye's "Habeas Viscus" in order to both bring race back into the centre of discussion, and to expand our view beyond issues of (legal) recognition.

\section{Homonormativity, Homonationalism and "Gay-Rights-as- Human-Rights"}

Lisa Duggan's notion of homonormativity (2002), and Jasbir Puar's development of the term towards an analysis of what she calls homonationalism (2007) are considered foundational when it comes to critiques of the role (racialised) figurations of "L-G-B-T-Q" play in the (de)construction of political communities and their boundaries. Other scholars have expanded upon them and introduced their own terminologies (see e.g. Rahman 20I4; Haritaworn, Kuntsman, and Posocco 2013). Duggan's homonormativity conceptualises the development of a gay (white, North-American, affluent middle-class) mainstream, whose political engagement, if present, is confined to campaigning for inclusion into the catalogue of rights and privileges that also mark and pro- 
tect heteronormativity (e.g. the right to marry and have children). Its aim is thus reaching respectability within heteronormative institutional constraints rather than fundamentally challenging these (2002). This domestication of a certain group of queers, Puar argues, goes hand in hand with their inclusion into a nationalist "us-vs-them" rhetoric (2006, 70), where (certain) normalised white queer bodies are used to exclude others racialised as non-white and/or Muslim (Puar 2006, 2007, 2013). Puar's conceptualisation of these exclusive inclusions as homonationalism relies therefore crucially on an analysis of the ascription of race to some (queer) bodies and not others as a decisive factor regarding whether someone is "acceptably queer" and suitable for inclusion into the national fold.

Following the concepts' initial introduction, scholars have applied homonormativity and particularly homonationalism to analyse how various actors (including state institutions, media, LGBTQ organisations and populist right-wing movements) employ LGBT rights in Western European contexts to mark the boundaries of so-called "European values" threatened by (hateful) racialised others described as inherently LGBTQ-phobic, sexist and patriarchal (Butler 2008; El-Tayeb 20I2; Haritaworn 2015; Jungar and Peltonen 2015; Kehl 2018). Similar narratives of "progressive West" vs. "oppressive East" have also been identified on an international level, in connection to an understanding of sexual rights as part of the global human rights catalogue (Sabsay, 20I2) and as part of geopolitical hierarchies and power struggles (Laskar 2014; Rahman 2014; Agathangelou 2013; Baker 20I7; Weber 2017; Rao 2014a). A growing body of literature within the field of International Relations deals with the ways in which struggles for LGBT rights have come to act as performative of nation-states, a symbolic marker of countries' in/tolerance and constructions of modernity and/or backwardness, as well as how sexual minority rights are now part of international "conditionality", highlighting how e.g. the Middle East, certain African countries and parts of Eastern Europe are constructed as "backward" and not "civilised" enough in relation to both Western Europe and North America (Ammaturo 2015; Kahlina 2015; Stychin 2004; Eden- 
borg 20I6). One frequently cited instance is then U.S. Secretary of State Hilary Clinton's declaration in 20I r that "gay rights are human rights," and how this became a leverage point in the Obama administration's foreign policy (Weber 20I6b; Rao 20I4a). Puar writes about this as "the human rights industrial complex" (Puar 2013), while Rahman calls it "homocolonialism" (Rahman 2015; see also Morgensen 2010). Agathangelou (2013) discusses how these international gay rights norms rely on anti-blackness. Rao draws our attention to how LGBT rights have been harnessed in support of hegemonic projects not only by Western powers but also by elites in the Global South (Rao 2010; see also Dutta 2013), and how through transnational practices of "locating homophobia" certain countries in the global South became places of hope (India, South Africa, Brazil) while others are places of phobia (Iran, Uganda, Jamaica) (Rao 20I4b). As we are entering the 2020s, these country-specific assessments might have to be reconsidered in the face of new conservative nationalisms on the rise in e.g. Brazil, but the overall mechanisms analysed by Rao remain acutely relevant.

Beyond analysing how demands for LGBT rights by state and nonstate actors are anchored in problematic homonormative, homonationalist and homocolonial narratives, these approaches express a general critique of the notion of sexual citizenship underlying "gay-rights-ashuman-rights" discourses. Based on Euro-American understandings of a universal liberal subject as claimant of human rights, it is considered to be a concept steeped in Western colonial and orientalist history, disregarding the socio-cultural specificity of notions of sexuality and gender identity and producing instead a universalist (and hegemonic) "sexual epistemology" through which certain ways of being and certain ways of making claims are normalised, while others are erased and excluded (Sabsay 2012; Massad 2007; Dutta 2013). The global spread of specific definitions and forms of LGBTQ activism are therefore said to result in a "westernisation" of LGBTQ identities and politics in non-western contexts (Altman 200I; Binnie 2004; Massad 2007) at the risk of ignoring local understandings and cultural meanings about sexualities as well as obscuring local political activism (Richardson 2005). 
While Puar's and Duggan's early analyses of homonationalism and homonormativity were essential to opening up for a critical engagement with LGBTQ politics' seemingly triumphant entry into the realm of the accepted and the respectable, and thus to a broadening of queer theory beyond an earlier focus on heteronormativity/heterosexism (see e.g. Cohen 1997 for an early critique of this), they have themselves not gone unchallenged. Aiming for further development and refinement of the analysis, I will now draw on various authors in order to critically engage with Puar's conceptualisation of homonationalism in particular, as well as some of the works that employ her concept directly to specific local contexts.

\section{"Gay-Rights-as-Human-Rights" and the Potential of Cautiously Deploying Universalism}

While many of the authors cited above seem to see "gay-rights-ashuman-rights" discourses as unambiguously detrimental, they have themselves been called out for risking dangerous simplifications in their analyses. Nikita Dhawan takes Puar to task for her anti-statist view on queer politics and LGBT rights which she sees as coming from positions of comparable "transnational privilege" that enable her to "reject 'pragmatic' politics in favour of more 'radical' interventions in the face of queer imperialism" (Dhawan 2013, 215). Seeing the state mostly as a malevolent monolithic power means not acknowledging "the importance of the state for those citizens who do not have access to transnational counterpublic spheres to address their grievances" (Dhawan 2013, 217) and who thus might be dependent on social recognition and legal protection by its institution. If we look at it exclusively like that, we disregard the state and its rights-granting powers as a potentially important arena of political activism in favour of a sole focus on the damage done by the selective granting of these rights (Dhawan 2013, 2016).

Some of those working within "Queer IR", a field that has gathered increasing traction with the rise of "the queer question" (Rao 2014a) onto the international political agenda, have taken up the question of whether it is at all possible to "not want rights" (Langlois 2015; Weber 
20I6b), drawing loosely on Gayatri Spivak (Spivak 2009). They reflect less categorically on the paradoxical way in which the extension of human rights to LGBTQ people grants certain entitlements and protections, while simultaneously creating exclusionary normative standards, thus further entrenching "existing institutions [...] which even purporting to be emancipatory, often constrain freedoms, generate inequality and entrench injustice" (Langlois 2015, 27). Human rights, Langlois says, "are about establishing particular normative boundaries;" which seems at first sight to create a theoretical paradox in relation to queer theory - "queer, if it is anything, is anti-normative. Establishing and policing boundaries is not supposed to be its brief" (Langlois 2015, 28). However, Rahul Rao has recently challenged this understanding of queer theory and human rights as mutually exclusive, despite being himself a fierce critic of the "gay-rights-as-human-rights" discourse (Rao 2010, 20I4a). He acknowledges that in some cases, "cautious deployment of universalism" can be in its place, in order to fulfil states' requirements for identifiable subjects, thus enabling the legal protection of at least some LGBTQ people (Rao 20I8, I46). He points out that this does not, as frequently assumed among human rights scholars (see e.g. Picq and Thiel 2015), exist in total opposition to queer theory by going back to what he calls "the most influential work in queer post-structuralism" (Rao 20I8, I46) - Judith Butler's Gender Trouble.

In the preface to the second edition, Butler acknowledges how her practical work on the International Gay and Lesbian Human Rights Commission had made her appreciate "the strategic utility of universalist categories so long as they were understood in nonsubstantial and openended ways, leaving them amenable to expansion through the claims of those who were not yet included within them" (Butler I990; quoted in Rao 2018 , I46). This means that as long as we remain aware of the risks of "seizing the tools of empowerment and emancipation available to us" (Rao 2018, I46), we should not be afraid of doing so based on an understanding of queer approaches as inherently disinterested in political recognition. As Cai Wilkinson reminds us, even the most accepted queer is still a queer, conditionally included, and thus remains in danger 
of being stripped of their rights (Wilkinson 20I7), which puts the ability to "not want rights" in favour of more radical solutions into perspective. This is a poignant reminder particularly at a time when political powers on the right are pushing to roll back recently won LGBT rights, such as the Trump administration's ban on transgender personnel serving in the US armed forces. Falling back on Puar's own initial analysis, we also know that those queers who are additionally subject(ed) to processes of racialisation are most acutely affected by this conditionality, an aspect I will be coming back to in more detail further down.

Rao encourages those engaged in discussions about both the role of the state and queer theory and politics to "conspire to use queer thought to introduce irresolvable tensions in IR" (Rao 20I8, I47), such as the ambiguity that is involved in not being able to not want rights, while also being aware of the normative, exclusionary and constraining aspects of these rights. As Langlois puts it: "Queering our politics, then $[. .$.$] is to refuse the seduction and embrace of the state at that point when$ the state seems to come on side; it is to recognize the queerness of that point: a moment of deep danger as well as one of liberation; a moment destabilizing in its possibilities for both emancipation and requisition" (Langlois 20I2, 35). Being aware of the complexity of this duality and making this complexity a part of our analyses, I argue, is necessary to ensure the continued relevance of concepts like homonationalism for critiques of how LGBTQ positionalities are used in processes of (national) boundary-making. We need to be able to maintain an awareness of the dangerous seduction of inclusion, but also the politics involved in inhabiting a position of not being able to "not want rights", rather than just focusing on the dangers of seduction and condemning the seduced.

\section{Maintaining Complexity through the Plural Logics of and/or}

If we want to attend more rigorously to the particular "queerness of that point", that is the ambiguity and complexity of the "gay-rights-ashuman-rights" discourse and its practical implications on the ground, I see the work IR-scholar Cynthia Weber has done on the plural logics of and/or as providing a useful approach. In her book on "Queer Inter- 
national Relations", Weber critiques claims about "the human rights industrial complex" (Puar 2013; Weber's emphasis) or "the neoliberal imperium" (Agathangelou 20I3; Weber's emphasis) on whose behalf "the human rights industrial complex" is mobilized (Weber 2016b, I I9). Drawing on Langlois, Brown and Zivi, she cautions us to acknowledge the "excessive potential of rights" (Weber 2or6b, irg) and the "extent to which our claims both reference and reiterate social conventions and norms, and yet have forces and effects that exceed them" (Zivi 20II, I9; quoted in Weber 20I6b). Not only can we not not want rights, by focussing exclusively on the homonormative, homonationalist and homocolonialist aspects of claiming gay rights as human rights, we also risk missing the numerous ways in which these claims might "practically and performatively exceed homonormativity, homonationalism, and (neo)imperialism" (Weber 20I6b, I20). If we do not pay attention to these, we run the danger of making these concepts more monolithic and universal than they are, thus endangering their critical analytical potential.

I identify this appeal for more complexity also in the work of Dhawan, who has previously pointed to the dangers a "sole focus on queer racism and homonationalism in the global North" poses when it leads scholars to neglect "homophobia and heterosexism in diasporic and postcolonial contexts, which are explained away as having been caused by, and as a reaction to, Western racism" (Dhawan 2013, I92). This, she says, is particularly dangerous not only because it exposes those who are "vulnerable to 'normative violence' [...] from both queer racism as well as postcolonial homophobia" (2013, I92), but also because it means we might miss occasions were actors, both colonial and postcolonial as well as across the religious-secular spectrum, collaborate with each other when it comes to furthering heteronormative agendas. One fairly recent example here might be the re-criminalisation of homosexuality in India in 2013 (Tonini 2016). Dhawan asks for a more multi-dimensional critique that allows us to see the (neo)imperialist, (neo)colonialist and racist aspects of homonationalism, homonormativity, and homocolonialism, while also keeping track of the fact that historically speaking, "both 
the empire and its antagonist, the anticolonial nation, are profoundly heteronormative projects" (Dhawan 2013, 205). It is, after all, a LGBTQ subject very much modelled after acceptable heteronormativity who is now increasingly employed to "narrate the nation" (Dhawan 2013, 205), which means we are far from done with the heteronormative, cissexist original. Instead, Dhawan argues, we need to be able to critically engage with more than one power structure at a time, neither neglecting the homonormative/homonationalist violence perpetrated by Western states nor the persecution of non-normative sexualities and gender identities within postcolonial societies.

For me, this argument can be connected directly to Weber, who points out that "like the institutions, structural arrangements, and practical dispositions that compose heteronormativity", homonormativity and homonationalism are specific both in their geopolitical and historical location, something which Duggan took up already when first coining the term homonormativity (Weber 20I6b, II6; Duggan 2002). Since their increased popularity both within and outside of academia, Weber argues, the ways in which these concepts have been applied by scholars and activists have sometimes neglected geographical and historical specificity, leading to "universalized, reified understandings of $[\ldots]$ homonormativity that seemingly apply in the same ways across time and space" (Weber 20I6b, II6). By treating homonormativity/homonationalism (in the form of e.g. "the human rights industrial complex") as if they were global phenomena, these analyses "flatten the subjectivities they investigate" (Weber 20r6b, I I6). Figurations like "the gay rights holder", the "gay patriot" as well as "the unwanted im/migrant" or "the terrorist", when read through such universalised understandings of homonormativity/homonationalism, become equally reified and monolithic in both their formations and resistances.

Weber illustrates how these figurations are never stable, "for every performance of a figuration depends upon innumerable particularities, including historical circumstances, geopolitical context, spatial location, social/ psychic/affective/political dispositions as well as perceived/attrib- 
uted traits (racial, sexual, classed, gendered, [dis] abled) of individuals in relation to the figurations they are presumed to inhabit, an individual's success, failure, or jamming of their assigned/assumed figuration as they performatively enact it, and how these performativities are received and read by others" (Weber 20I6a, I6). Universal figures are therefore "never as universal as they may at first appear to be" (Weber 2016b, 137) and "institutional arrangements of power/knowledge/pleasure-be they heteronormativities and/or homonormativities-are likewise less stable than they appear to be" (Weber 20I6a, I7). Weber suggests that if we want to account for these instabilities, we need to move from binary either/or logics of power (and antinormative-vs-normative) to and/or logics. As an international relations scholar, she applies these "queer logics of statecraft" particularly to discourses on sovereignty, but I argue that they have useful implications for queer theory at large if we want to approach homonationalist/homonormative/homocolonialist mobilisations in all their potential complexities.

Weber's main argument is that existing analyses of homonationalism and homonormativity are built on the either/or logics which portray the normal and the perverse as being mutually exclusive while also being constitutive of each other. This logic, she writes, is built on an either/or understanding of power, which means that "at the heart of contemporary constructions of homonormativity is an antinormative-vs-normative binary logic that reproduces the very antinormative-vs-normative binary logic that theorists of these homonormativities investigate" (Weber 20I6b, I I6). By applying this logic, we miss that someone (or something) might not be understandable through one single fixed meaning, but might require an understanding of how "a person or a thing is constituted by and simultaneously embodies multiple, seemingly contradictory meanings that may confuse and confound a simple either/or dichotomy" (Weber 20I6b, 9). Her main example is that of Conchita Wurst/Tom Neuwirth, the winner of the 2014 Eurovision Song Contest, whom she sees as "a performative embodiment of a plural logoi" (Weber 20r6a, 20). A bearded drag queen, he/she has been read through "vast matrices of sexes, genders, and sexualities that minimally include either male 
or female, masculine or feminine, heterosexual or homosexual, normal or perverse as well as simultaneously male and female, masculine and feminine, heterosexual and homosexual, normal and perverse" (Weber 2016a, 20).

I argue that these plural logics can be read as queer logics, which are not limited to describing the ways in which the performatively perverse creates the appearance of the performatively normal or vice versa. They expand upon this by instead "understanding the presumed singularity and coherence of its available choices ([...] either normal or perverse), their resulting subjectivities [only normal or perverse], and their presumed ordering principles (either hetero/homonormative or disruptively/disorderingly queer) as the social, cultural, and political effects of attempts to constitute them as if they were singular, coherent, and whole" (Weber 2016a, I9). Relating this back to the "gay-rightsas-human-rights" discourse, and its homonormative, homonationalist, and homocolonialist implications, it is the application of a plural and/ or logic that allows for an adequate exploration of the excessive political potential of this discourse, as well as seeing specificities, ambiguities and contingencies of the figurations and subjectivities it performed through, mobilises and produces.

Acknowledging these appeals for queer theory to account more rigorously for ambiguities and complexities in our analyses of homonormative, homonationalist and homocolonialist formations, how do we continue to move forward in ongoing attempts to analyse and critically engage with the various ways in which LGBTQ issues have become entangled in projects of boundary-making? Melanie Richter-Montpetit has pointed out that while Weber's analysis includes racism and racialised discourses, her Foucauldian approach to power and sexuality rest on an understanding of (hu)man prior to racialisation, thus underestimating "the extent to which the modern (homo/sexual) subject is always already racialised" (Richter-Montpetit 2018, 23I). I think that the above contributions add crucial aspects for developing the potential for complexity of analyses of how LGBT rights are employed in processes of boundary-making. At the same time, it seems that one central aspect 
of Puar's initial conceptualisation slips out of focus in these critiques: The various ways in which sexualised/gendered difference is always also racialised (Collins 2009), and how this matters for the "messiness" of contemporary inclusions/exclusions as well as for the question of which queer bodies can and cannot afford to "not want rights". This is particularly crucial in contexts where "the law" is seen as something "neutral", "extra-racial", while in effect being a big part of "assemblages of racialisation" (Weheliye 20I4). In the following section, I will therefore argue for the continued need for queer theory to (re-)engage more deeply with questions of racialisation precisely in order to account for the ambiguities and complexities writers like Weber and Dhawan remind us of.

\section{The Queer Potential of Racialised Difference}

Processes of racialisation have a long tradition as a method for the production of respectable and innocent genders and sexualities considered worthy of visibility, recognition and protection (Haritaworn 2015, 95; Laskar 2007, 2015b) and are closely linked to colonial thought and policymaking, including both racial hierarchies and domination between bodies racialised as superior or inferior (Grosfoguel, Oso, and Christou 2015) and the creation of (threatening) constitutive outsides (Laskar 2007; Yuval-Davis 2006; Haritaworn 2015). Using the inclusion of certain kinds of LGBTQ people in order to demarcate a dangerous, threatening or otherwise problematic "other" is predicated upon an understanding of progress and modernity inspired by European Enlightenment thinking, within which the acknowledgement of women's rights and LGBT rights becomes a measurement of "how far" a country, nation or community has "progressed". LGBT rights can "thus be read as a marker of the latest stage of the progressive teleological modernity of the West", while also pointing towards a more general "Western civilizational exceptionalism" (Rahman 2014, 278). These temporal-developmental differentiations between "the self" and "the other" (and the various implications of being seen as one or the other), are maintained by a dialectic of respectability that relies crucially on sexuality and gender identity as always already also racialised. 
We can draw on a number of postcolonial scholars who have analysed how these processes of objectification are based on binary thinking, where each term gains meaning only in relation to an oppositional counterpart (Collins 2009). The notion of modern (hu)Man is thus dependent upon objectifying those racialised as non-white as the oppositional other, separating the "knowing self" from the "known object" (Richards I980; quoted in Collins 2009, 78), to be manipulated and controlled (Fanon 1967). "Race as a mode of governing and knowing" (Moffette and Vadasaria 2016, 294), performed through the self-other dialectic described above, entails that there are long-established grids of intelligibility for the ways in which populations or individuals racialised as nonwhite are read as threatening and violent (Moffette and Vadasaria 2016, 293-295) which are crucial to our understanding of much of the rhetoric employed in contemporary "exclusive inclusions" around LGBT rights and issues. They build on "interconnected genealogies of race" (Moffette and Vadasaria 2016, 294) and the longstanding colonial history of race as "an administrative and anthropological category" (Hesse 2004, I3; quoted in Moffette and Vadasaria 2016), even if they increasingly take the form of "cultural" rather than biological racism (Gilroy I993; Essed I996; Grosfoguel, Oso, and Christou 2015; Martinsson, Griffin, and Giritli Nygren 2016).

The racial grammar that demarcates difference through this self-other dialectic has enabled various figurations of "the other", including the savage, the primitive, the colonized (Laskar 2007; McClintock 1995) and the "victim" (Bracke 20I2; Horton 20I7; Jungar and Peltonen 2015), but also "the unwanted im/migrant" (Luibhéid 2008b), and "the terrorist," (Puar and Rai 2002; Puar 2007), all of whom rely in one way or another on civilizational discourses born within the context of modern colonialism, and all of whom have made possible specific (more or less violent) practices of intervention and population management. "The hateful other" who threatens (white) queers (Haritaworn 2015) is just the latest incarnation in this long line. While scholars have acknowledged the ways in which these various figurations also have been sexualised and gendered as the weird, the deviant, the morally dangerous 
(Laskar 2015a, 2015b), thus calling attention to how the policing of racialised subjects and the policing of queer subjects have gone hand in hand, queer theory has not always been successful at addressing the fact that there is no "unracialised" sexuality/gender and that sexualised/ gendered difference is always also racialised. I argue that awareness of the ways that bodies racialised as non-white have been and are read and treated as always potentially threatening is crucial for our understanding of how certain individuals are more susceptible to the dangers of not being included in the "gay-rights-as-human-rights" catalogue, thus being even less able to afford a position of "not wanting rights". But taking a queerer look at racialisation can actually take us beyond the realm of the self-other dialectic, thus potentially adding to our ability to account for homonormative/homonationalist processes in all their complexity.

In order to do this, I draw on "Habeas Viscus" by black studies scholar Alexander Weheliye, in which he expands upon the self-other/ subject-object dialectic by investigating what he calls those racializing assemblages which "constru[ct] race not as a biological or cultural classification but as a set of sociopolitical processes that discipline humanity into full humans, not quite humans, and nonhumans" (Weheliye 2014, 4) and as such play an essential role in the construction of modern subjectivity. His interest goes beyond merely analyzing these hierarchical processes, as he aims for a disarticulation of "the human from the world of Man" (Weheliye 2014, 32) and an unearthing of alternative ways of being human beyond modern (Western) discourses of subjecthood that require legal recognition, and as such "one form of subjugation [of certain minorities] at the expense of others" (Weheliye 20I4, 8I). Falling back on black feminist writers Hortense Spiller and Sylvia Wynter, Weheliye identifies "the flesh" as a way of considering "alternative versions of humanity" (Weheliye 20I4, Io), namely those which exist outside the realm of the recognizable. This, I think, applies to non-normative sexualities and genders along similar lines of (non)recognition as processes of racialisation, something which Weheliye alludes to, but not develops. In his account, the violence of historical relations of dominance based 
on processes of racialisation creates "fleshly surplus" (Weheliye 20I4, 2) that evades capture, where alternative ways of humanity can be identified outside the realm of Man. His Habeas viscus ("You shall have the flesh") thus both pre- and exceeds the body referred to in Habeas corpus, commonly acknowledged as the law's utterance of recognition of subjecthood. Black studies, Weheliye argues, is particularly suited to "perceive and understand a world in which subjection is but one path to humanity" because of the way in which black cultures have been routinely excluded from access to "Man's language, world, future, or humanity" (Weheliye 2014,135 ). Looking at how humanity has been "imagined and lived by those subjects excluded from [the domain of Man]” (Weheliye 2014, 8) thus unsettles and displaces (or, as I would put it, "queers") the centrality of legal recognition with regard to who counts as "human". This queering of the category of "the human" by way of Weheliye's analysis of assemblages of racialisation thus has implications also for those who are "non-human" for other reasons than their being racialised as non-white. In turn the potential for competition between minoritized groups for legal recognition as a scarce resource becomes diffused (Weheliye 2014, I3), and new intersectional alliances become possible.

I argue that if we combine Weheliye's striving for alternative modes of existence, life, humanity, freedom and liberation beyond the recognition of the law (based in the acknowledgement that racialised assemblages have and will continue to exclude certain populations from that recognition) with Weber's search for a plural logic of the and/or (challenging the presumed singularity and coherence of concepts such as "the normal" or "the perverse"), we will be better equipped to conduct our analyses of homonormative, homonationalist and homocolonialist moves to position LGBTQ people as boundary-makers in various national and international political contexts. Applying a plural logic of the and/or not only exposes the instability of these boundary-makingmoves, it also enables us to investigate the beforementioned "excessive potential of rights" (Weber 20I6b, IIg) in discourses such as the one about "gay-rights-as-human-rights." Weheliye's work, on the other hand, brings to our renewed attention the role racialisation plays in the 
separation of the human from the non-human via legal recognition, and then raises the stakes by encouraging us to look beyond, for the political potential for freedom and emancipation that lies with those who have been and continue to be excluded from subjecthood. Together, these approaches not only nuance claims about the homonormative, homonationalist, or homocolonialist character of certain political processes of boundary-making, they also help us analyse the ways in which LGBTQ people are variously positioned to deal with these. They thus go beyond academic relevance, enabling us to direct our activist interventions in the most efficient way.

\section{Conclusion}

The literature on homonormativity, homonationalism and homocolonialism, and the ways in which it has been expanded upon since the early 2000 s has managed to question and opened up what has often been a single-issue focus on heterosexuality and its binary gender norms, increasing our ability to see beyond heteronormativity and to more fully account for the intersectional complexity of queer positionalities. In this article I have developed these analyses, arguing that if we want to understand the role figurations of "L-G-B-T-Q" play in projects of national and international boundary-making as well as the ways in which LGBTQ people across the globe are variously positioned to deal with these mobilisations, we need to both expand our theoretical conceptualisation of homonationalism and re-focus on some central aspects of the original concept. While Weber's logic of and/or enables us to nuance and challenge seemingly straightforward binary narratives about homonormativities, homonationalisms and homocolonialisms, thus accounting more thoroughly for the complexities and ambiguities that new (global) tales of LGBTQ inclusion entail, human rights scholars' calls for the "cautious employment of universalism" point out the need to engage with the excessive potential of "gay-rights-as-humanrights" discourses as more than just expressions of (neo)colonialism and (neo)imperialism. Additionally, racialisation and the role it plays in the self/other (or human/not-quite-human) dialectic underlying much 
of the making of sexualised and/or gendered difference needs to be brought back into focus. It draws our attention to how certain individuals and groups are more susceptible to the dangers of not being included in the "gay-rights-as-human-rights" catalogue, thus being even less able to afford a position of "not wanting rights", but through the work of black studies scholars like Weheliye also opens up our ability to look beyond these processes of boundary-making towards "queer" life and humanity outside the realm of legal recognition. Paying attention to these complexities and potentials, while maintaining an acute awareness of the widely varying ability to at all want or "not want" access to rights and recognition, will improve both our ability for academic analyses and our potential for political interventions. As the rise of various "new" nationalisms across the globe brings about backlashes on LGBT rights even for the most privileged among us, fights for legal rights will most likely have to continue to go hand in hand with our most nuanced critiques of that very system of recognition in all its homonormative, homonationalist, and homocolonialist forms.

KATHARINA KEHL is a doctoral student at the School of Global Studies at the University of Gothenburg. Her research focusses on questions of gender, sexuality and race, and the othering of groups and individuals along these lines. In her dissertation, she looks at the ways in which gender and sexuality are being used in Swedish/ Northern European migration discourses to selectively include and exclude minorities, and the implication this has for LGBTQIA* people, those who are racialised, and queer feminist movements.

\section{REFERENCES}

Agathangelou, Anna M. 2013. "Neoliberal Geopolitical Order and Value." International Feminist Journal of Politics I5 (4): 453-76. https://doi.org/10.1080/14616742.2013.841560. Altman, David. 20or. Global Sex. Chicago: University of Chicago Press.

Ammaturo, Francesca Romana. 2015. "The 'Pink Agenda': Questioning and Challenging European Homonationalist Sexual Citizenship.” Sociology 49 (6): I I 5 I-66. https://doi.org/IO.II77/0038038514559324. 
Baker, Catherine. 2017. "The 'Gay Olympics'? The Eurovision Song Contest and the Politics of LGBT/European Belonging." European Journal of International Relations 23 (I): 97-I2r. https://doi.org/Io.1177/I354066rir6633278.

Binnie, Jon. 2004. "The Globalization of Sexuality." https://doi.org/Io.250I/JAR -5 I4-564-570.

Bracke, Sarah. 201 2. "From ‘saving Women' to 'Saving Gays': Rescue Narratives and Their Dis/Continuities." European Journal of Women's Studies I9 (2): 237-52. https:// doi.org/Io.I I77/I3505068II 435032.

Butler, Judith. 1990. Gender Trouble: Feminism and the Subversion of Identity. New York; London: Routledge.

-. 2008. "Sexual Politics, Torture, and Secular Time." The British Journal of Sociology 59 (I): I-23. https://doi.org/Io.IIII/j.I468-4446.2007.00176.x.

Cohen, Cathy J. I997. "Punks, Bulldaggers, and Welfare Queens." GLQ: A Journal of Lesbian and Gay Studies 3: 437-65.

Collins, Patricia Hill. 2009. Black Feminist Thought: Knowledge, Consciousness, and the Politics of Empowerment. 2nd ed. New York; London: Routledge.

Dhawan, Nikita. 2013. "The Empire Prays Back: Religion, Secularity, and Queer Critique." Boundary 240 (I): I9I-222. https://doi.org/IO.I215/01903659-2072918.

-. 2016. "Homonationalism and State-Phobia: The Postcolonial Predicament of Queering Modernities." In Queering Paradigms V: Queering Narratives of Modernity, edited by M. Viteri and Manuela Lavinas Picq, 5 I-68. Oxford: Peter Lang Publishing.

Duggan, Lisa. 2002. "The New Homonormativity. The Sexual Politics of Neoliberalism." In Materialising Democarcy. Towards a Revitalised Cultural Politics, edited by Dana Nelson and Russ Castronova, I75-94. Durham: Duke University Press.

Dutta, Aniruddha. 2013. "Legible Identities and Legitimate Citizens." International Feminist Journal of Politics I5 (4): 494-514. https://doi.org/10.1080/I4616742.2013.818279.

Edenborg, Emil. 20I6. "Nothing More to See: Contestations of Belonging and Visibility in Russian Media." Lund University; Malmö University. http://lup.lub.lu.se/ record/8840122.

E1-Tayeb, Fatima. 20r 2. “Gays Who Cannot Properly Be Gay': Queer Muslims in the Neoliberal European City." European Journal of Women's Studies I9 (I): 79-95. https://doi.org/ro.1177/I35050681 I426388.

Essed, Philomena. 1996. Diversity: Gender, Color, and Culture. Amherst: University of Massachusetts Press.

Fanon, Frantz. 1967. Black Skin, White Masks. New York: Grove Press.

Gilroy, Paul. 1993. The Black Atlantic: Modernity and Double Consciousness. Cambridge, Mass.: Harvard University Press.

Grosfoguel, Ramon, Laura Oso, and Anastasia Christou. 2015. "Racism', Intersectionality and Migration Studies: Framing Some Theoretical Reflections.” Identities 22 (6): 635-52. https://doi.org/10.1080/1070289X.2014.950974. 
Haritaworn, Jin. 2015. Queer Lovers and Hateful Others: Regenerating Violent Times and Places. London: Pluto Press.

Haritaworn, Jin, Adi Kuntsman, and Silvia Posocco. 2013. "Murderous Inclusions." International Feminist Journal of Politics I5 (4): 445-52. https://doi.org/10.1080/I46I6 742.2013 .841568 .

Hesse, Barnor. 2004. "Im/Plausible Deniability: Racism’s Conceptual Double Bind.” Social Identities: Journal of the Study of Race, Nation and Culture Io (I): 9-29.

Horton, Brian A. 2017. "What's so 'Queer' about Coming out? Silent Queers and Theorizing Kinship Agonistically in Mumbai.” Sexualities, September, I-I6. https://doi.org/10.1177/1363460717718506.

Jungar, Katarina, and Salla Peltonen. 2015. “Saving Muslim Queer Women from Muslim Hetero- Patriarchy'. Savior Narratives in LGBTI Youth Work.” NORMAInternational Journal for Masculinity Studies Io (2): I36-49. https://doi.org/Io.1080/I8 902138.2015 .1050862.

Kahlina, Katja. 2015. "Local Histories, European LGBT Designs: Sexual Citizenship, Nationalism, and 'Europeanisation' in Post-Yugoslav Croatia and Serbia." Women's Studies International Forum 49: 73-83. https://doi.org/Io.ror6/j.wsif.2014.07.006.

Kehl, Katharina. 2018. "In Sweden, Girls Are Allowed to Kiss Girls, and Boys Are Allowed to Kiss Boys': Pride Järva and the Inclusion of the 'LGBT Other' in Swedish Nationalist Discourses." Sexualities 2I (4): 674-9r. https://doi. org/Io.1177/136346071774862 I.

Langlois, Anthony J. 2012. "Human Rights in Crisis? A Critical Polemic Against Polemical Critics." Journal of Human Rights i I (4): 558-70. https://doi.org/IO.1080/I4754835.2012.702473.

-. 2015. "Human Rights, LGBT Rights, and International Theory." In Sexualities in World Politics, edited by Manuela Lavinas Picq and Markus Thiel, 23-37. London; New York: Routledge.

Laskar, Pia. 2007. "Förnuft och instinkt. Föreställningar om ras, klass och sexualitet under 1800-Talet." In Framtidens feminismer: intersektionella interventioner i den feministiska debatten, edited by Paulina de los Reyes and Satu Gröndahl, 44-65. Stockholm: Tankekraft förlag.

-. 20I4. "The Illiberal Turn: Aid Conditionalis and the Queering of Sexual Citizenship." Lambda Nordica I: 87-100.

- 2015a. "De andras sexualitet som hot- och motbild." In Sexualpolitiska nyckeltexter, edited by Klara Arnberg, Pia Laskar, and Fia Sundevall, 158-66. Stockholm: Leopard.

- 2015b. "The Construction of 'Swedish' Gender through the Other as a CounterImage and Threat." In What's in a Word? Antiziganism, edited by Jan Selling, Markus End, Hristo Kyuchukov, Pia Laskar, and Bill Templer, I38-53. Cambridge: Cambridge Scholars Publishing. 
Luibhéid, Eithne. 2008a. "Queer / Migration: An Unruly Body of Scholarship." GLQ: A Journal of Lesbian and Gay Studies I4 (2-3): 169-90.

https://doi.org/IO.I215/10642684-2007-029.

-. 2008b. "Sexuality, Migration, and the Shifting Line between Legal and Illegal

Status." GLQ: A Journal of Lesbian and Gay Studies I4 (2-3): 289-315.

https://doi.org/IO.I215/10642684-2007-034.

Martinsson, Lena, Gabriele Griffin, and Katarina Giritli Nygren, eds. 20r6. Challenging the Myth of Gender Equality in Sweden. Bristol: Policy Press.

Massad, Jospeh. 2007. Desiring Arabs. Chicago: University of Chicago Press.

McClintock, A. 1995. Imperial Leather: Race, Gender and Sexuality in the Colonial Context. London: Routledge.

Moffette, David, and Shaira Vadasaria. 20r6. "Uninhibited Violence: Race and the Securitization of Immigration." Critical Studies on Security 4 (3): 29I-305. https://doi.org/Io.1080/21624887.2016.1256365.

Morgensen, S. L. 2oIo. "SETTLER HOMONATIONALISM: Theorizing Settler Colonialism within Queer Modernities." GLQ: A Journal of Lesbian and Gay Studies I6 (I-2): I05-3I. https://doi.org/IO.I215/10642684-2009-0I5.

Picq, Manuela Lavinas, and Markus Thiel, eds. 2015. Sexualities in World Politics: How LGBTQ Claims Shape International Relations. London; New York: Routledge.

Puar, Jasbir K. 2006. “Mapping US Homonormativities.” Gender, Place E̋ Culture I3 (I): 67-88. https://doi.org/ro.1080/o9663690500531014.

- 2007. Terrorist Assemblages: Homonationalism in Queer Times. Durham: Duke University Press.

-. 2013. "Rethinking Homonationalism." International Journal of Middle East Studies 45 (2): 336-39. https://doi.org/Io.1017/Soo2074381300007X.

Puar, Jasbir K., and Amit S. Rai. 2002. "Monster, Terrorism, Fag:The War on Terrorism and the Production of Docile Patriots." Social Text 20 (3): I I $7-48$. http://muse.jhu.edu/journals/social_text/vo2o/20.3puar.html.

Rahman, Momin. 2014. "Queer Rights and the Triangulation of Western Exceptionalism." Journal of Human Rights I3 (3): 274-89. https://doi.org/Io.1080/I4754835.2014.9I92I4.

-. 2015. "Sexual Diffusions and Conceptual Confusions." In Sexualities in World Politics, edited by Manuela Lavinas Picq and Markus Thiel. London; New York: Routledge.

Rao, Rahul. 2010. Third World Protest. Oxford: Oxford University Press. https://doi.org/Io.1093/acprof:oso/9780199560370.001.00or.

—. 2014a. "Queer Questions." International Feminist Journal of Politics I6 (2): 199-217. https://doi.org/I0.1080/I4616742.2014.901817.

-. 2014 b. "The Locations of Homophobia." London Review of International Law 2 (2): I69-99. https://doi.org/ro.ro93/lril/1ruoro.

—. 20I 8. "The State of 'Queer IR.” GLQ: A Journal of Lesbian and Gay Studies 24 (I): I39-49. https://doi.org/IO.I2I5/I0642684-425453I. 
Richards, Dona. 1980. "European Mythology: The Ideology of 'Progress.” In Contemporary Black Thought, edited by Molefi Kete Asante and Abdulai S. Vandi, 59-79. Beverly Hills: SAGE.

Richardson, Diane. 2005. "Desiring Sameness? The Rise of a Neoliberal Politics of Normalisation.” Antipode. https://doi.org/Io.I I I I/j.0066-48I 2.2005.00509.x.

Richter-Montpetit, Melanie. 2018. "Everything You Always Wanted to Know about Sex (in IR) but Were Afraid to Ask: The 'Queer Turn' in International Relations.” Millennium: Journal of International Studies 46 (2): 220-40. https://doi.org/IO.II77/0305829817733131.

Sabsay, Leticia. 20r2. "The Emergence of the Other Sexual Citizen: Orientalism and the Modernisation of Sexuality." Citizenship Studies I6 (5-6): 605-23. https://doi.org/10.1080/13621025.2012.698484.

Spivak, Gayatri Chakravorty. 2009. Outside in the Teaching Machine. London: Routledge.

Stychin, Carl F. 2004. "Same-Sex Sexualities and the Globalization of Human Rights Discourse.” McGill Law Journal 49: 95 I-68. http://lawjournal.mcgill.ca/issues.php. Tonini, Maria. 2or6. The Ambiguities of Recognition: Young Queer Sexualities in Contemporary India. Lund: Lund University, Department of Gender Studies.

Weber, Cynthia. 2or6a. "Queer Intellectual Curiosity as International Relations Method: Developing Queer International Relations Theoretical and Methodological Frameworks." International Studies Quarterly 60 (I): I I-23. https://doi.org/Io.I I I I/isqu.I22 I2.

-. 2016b. Queer International Relations. New York: Oxford University Press. https://doi. org/Io.1093/acprof:oso/9780199795857.001.0001.

—. 2017. “Thinking about Queer Wars: 'International Polarization' and Beyond." Australian Journal of International Affairs $7 \mathrm{I}$ (3): 23I-35. https://doi.org/Io.1080/I0357718.2017.I290046.

Weheliye, Alexander G. 2014. Habeas Viscus. Durham: Duke University Press.

Wilkinson, Cai. 2017. "Are We Winning? A Strategic Analysis of Queer Wars.” Australian Journal of International Affairs 7I (3): 236-40. https://doi.org/Io.1080/I03577I8.2017.I290049.

Yuval-Davis, Nira. 2006. "Belonging and the Politics of Belonging." Patterns of Prejudice 40 (3): 197-214. https://doi.org/10.1080/0031322060076933I.

Zivi, Karen. 20r r. Making Rights Claims. Oxford: Oxford University Press. 